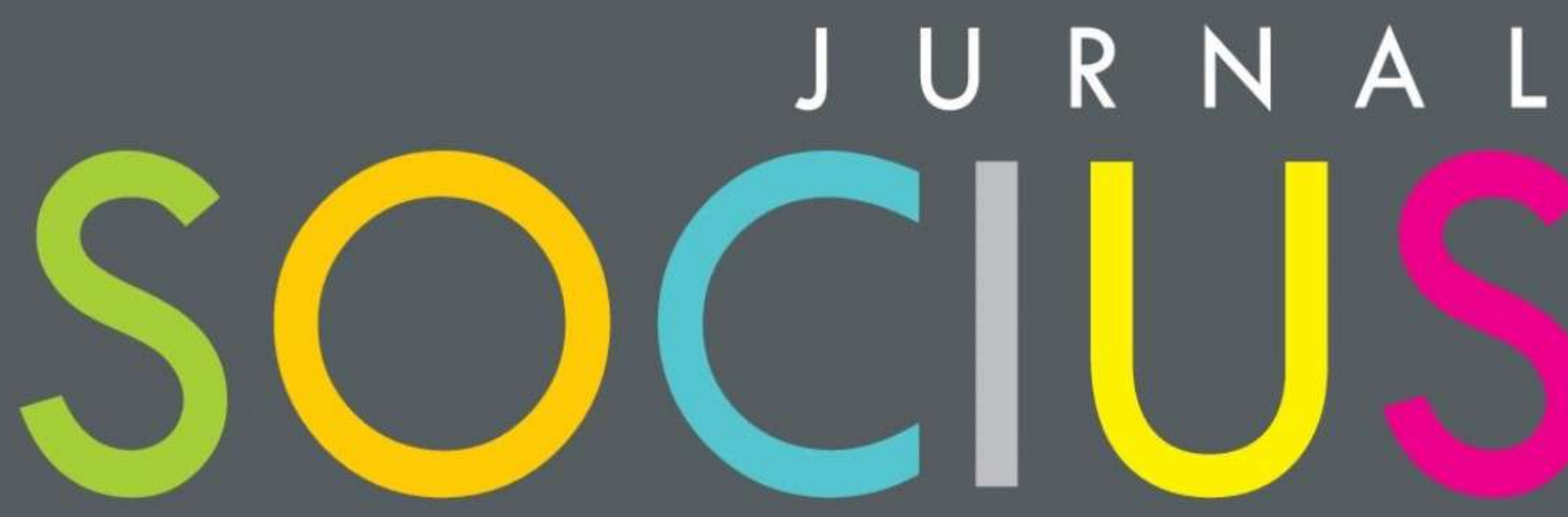

Journal of Sociology Research and Education

DITERBITKAN OLEH :

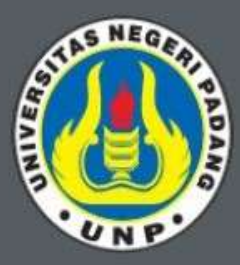

LABOR JURUSAN SOSIOLOGI FAKULTAS ILMU SOSIAL UNIVERSITAS NEGERI PADANG

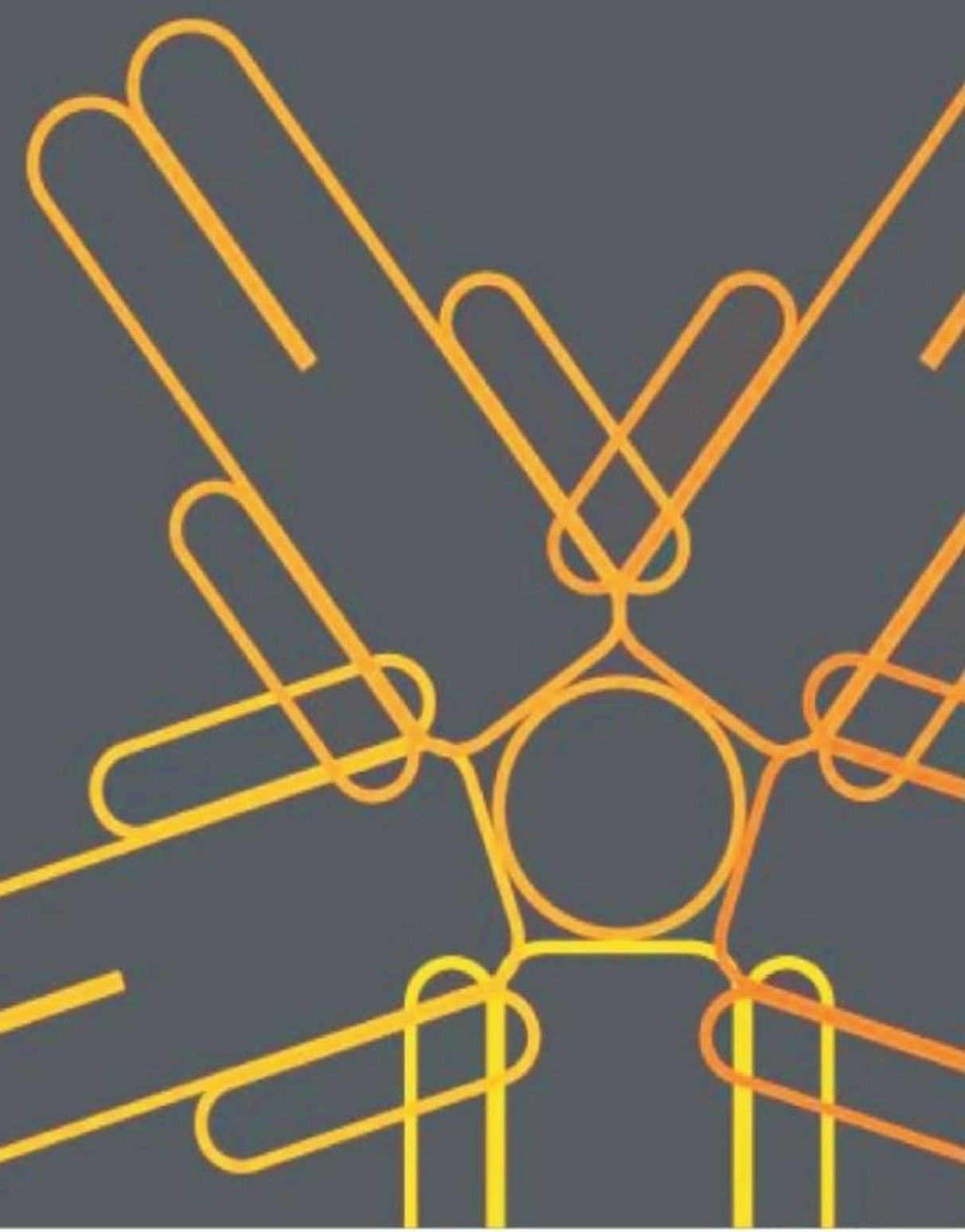




\section{SOCIUS}

Vol. 6, No.1, Th. 2019

ISSN : 2356-4180 (cetak)

2442-8663 (online)

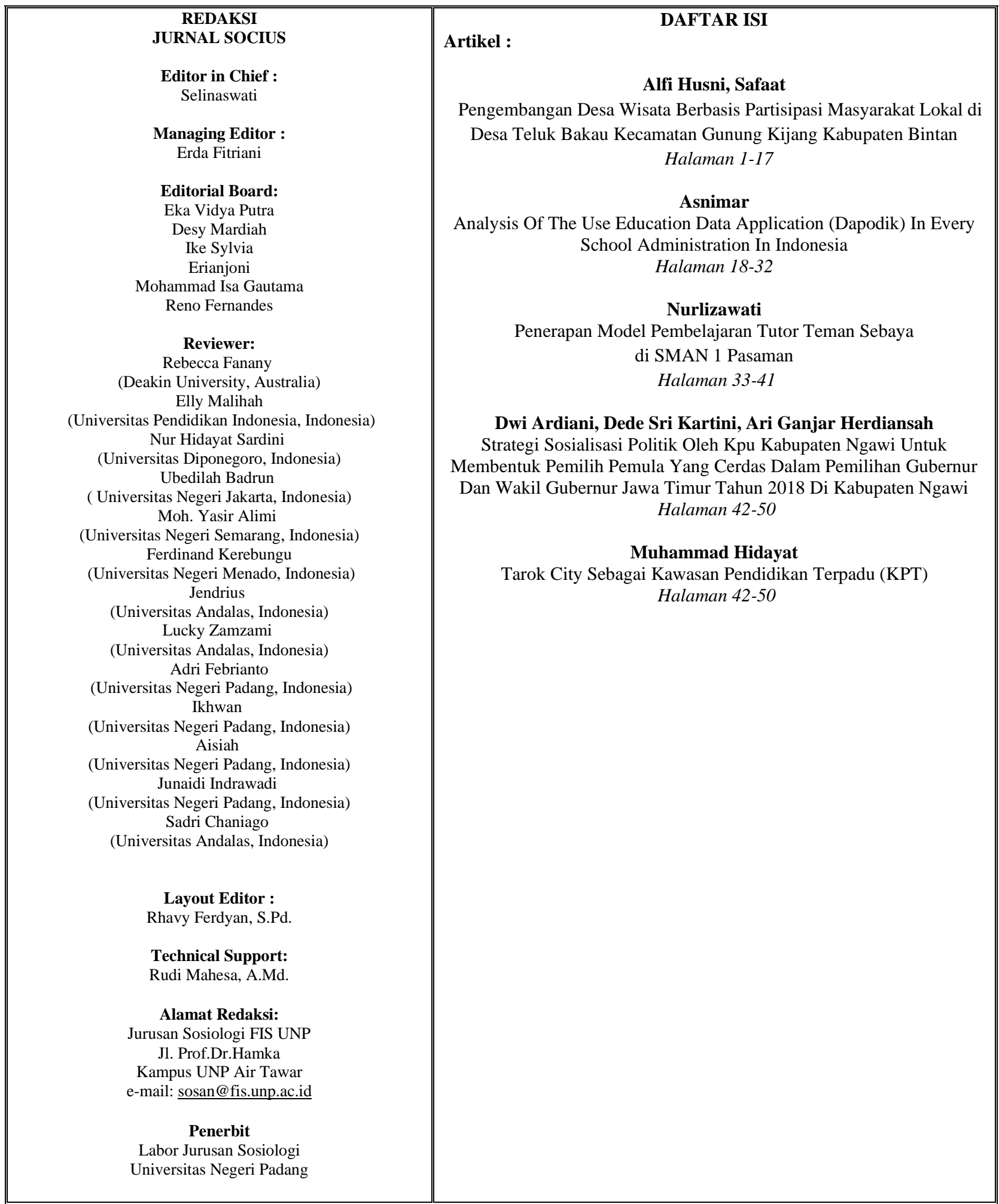




\title{
STRATEGI SOSIALISASI POLITIK OLEH KPU KABUPATEN NGAWI UNTUK MEMBENTUK PEMILIH PEMULA YANG CERDAS DALAM PEMILIHAN GUBERNUR DAN WAKIL GUBERNUR JAWA TIMUR TAHUN 2018 DI KABUPATEN NGAWI
}

\author{
Dwi Ardiani ${ }^{1}$, Dede Sri Kartini ${ }^{2}$, Ari Ganjar Herdiansah ${ }^{3}$ \\ 1,2,3Universitas Padjajaran \\ Email: ardiani0303@gmail.com
}

\begin{abstract}
Abstrak
Sosialisasi politik penting untuk meningkatkan partisipasi. Apalagi dengan kemungkinan penyalahgunaan calon pemilih oleh politisi dan partai politik. Pemilih pemula adalah pemilih potensial yang memiliki kekhasan sendiri dengan sejumlah besar pemilih. Penelitian ini menggunakan metode penelitian kualitatif deskriptif dimana data diperoleh dengan wawancara mendalam dan dokumentasi. Informan dalam penelitian ini adalah anggota Divisi Partisipasi Masyarakat KPU Kabupaten Ngawi dan SDM, Sekretaris Komisi Pemilihan Umum Kabupaten Ngawi, Panitia Pemilihan Distrik, Panitia Pemungutan Suara, Relawan Demokrat, Tokoh Masyarakat, Tokoh Akademik dan Pemilih Pemula dengan mengambil sampel menggunakan purposive sampling. Lokasi penelitian adalah Kabupaten Ngawi, dimana pada tahun 2018 Gubernur dan Wakil Gubernur Jawa Timur Terpilih secara bersamaan. Hasil dari penelitian ini adalah strategi sosialisasi politik yang dilakukan oleh KPU Kabupaten Ngawi untuk membentuk pemilih pemula yang cerdas dalam Pemilihan Gubernur dan Wakil Gubernur Jawa Timur termasuk perumusan strategi dan perencanaan jangka panjang, tahapan pemilihan tindakan menggunakan strategi serangan dan strategi persuasi dan tahap alokasi sumber daya organisasi menggunakan strategi penguatan.
\end{abstract}

Kata Kunci : Strategi, Sosialisasi Politik, Partisipasi pemilih, Pemilih Pemula, Pemilukada

\begin{abstract}
Political socialization is important to increase participation. Especially with the possibility of misuse of potential voters by politicians and political parties. Beginner voters are potential voters who have their own peculiarities with a large number of voters. This research uses descriptive qualitative research method where data is obtained by in-depth interviews and documentation. Informants in this study were members of the Ngawi Regency KPU Community Participation Division and HR, Secretary of the Ngawi Regency Election Commission, District Election Committee, Voting Committee, Democratic Volunteers, Community Leaders, Academic Figures and Beginner Voters by drawing samples using purposive sampling. The research location is Ngawi Regency, where in 2018 the East Java Governor and Deputy Governor Elected simultaneously. The results of this study are political socialization strategies carried out by the KPU of Ngawi Regency to form smart beginner voters in the Election of Governor and Deputy Governor of East Java including the formulation of strategy and longterm planning, action selection stages using attack strategies and persuasion strategies and the stage of allocation of organizational resources using reinforcement strategies.
\end{abstract}

Keywords: Strategy, Political Socialization, Voter Participation, Beginner Voters, Election

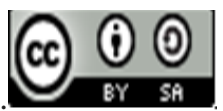

Received: January 28, 2019

Revised: April 24, 2019

Available Online: June 28, 2019

Jurnal Socius: Journal of Sociology Research and Education Vol. 6, No.1, Th. 2019

ISSN: Online 2442-8663 - Print 2356-4180

Copyright $\odot 2019$, Jurnal Socius 


\section{Pendahuluan}

Pemilihan Kepala Daerah secara langsung merupakan bentuk perwujudan demokrasi dimana masyarakat ikut berpartisipasi dilibatkan secara langsung dalam pemilihan kepala daerah. Partisipasi adalah kegiatan seseorang atau kelompok orang untuk ikut serta secara aktif dalam kehidupan politik, antara lain dengan jalan memilih pimpinan negara dan secara langsung atau tidak langsung memengaruhi kebijakan pemerintah (public policy). Kegiatan ini mencakup tindakan seperti memberikan suara dalam pemilihan umum, menghadiri rapat umum, mengadakan hubungan (contacting) atau lobbying dengan anggota parlemen atau pejabat pemerintah, menjadi anggota partai atau salah satu gerakan sosial dengan direct actionnya dan sebagainya. (Budiarjo M. , 2016, hal. 367). Semakin tinggi partisipasi menandakan bahwa rakyat mengikuti, memahami, dan melibatkan diri dalam kegiatan kenegaraan. Sebaliknya partisipasi yang rendah menjadi penanda bahwa rakyat kurang menaruh apresiasi atau minat terhadap masalah atau kegiatan kenegaraan.

KPU menyadari akan pentingnya sosialisasi politik untuk meningkatkan partisipasi. Terutama dengan adanya kemungkinan penyalahgunaan potensi pemilih pemula oleh kalangan politisi maupun partai politik. Pemilih pemula adalah mereka yang masuk usia memilih dan yang akan menggunakan hak pilihnya untuk pertama kali dalam pemilu / pemilukada. Dengan siklus pemilihan di Indonesia yang digelar setiap lima tahun sekali maka kisaran usia pemilih pemula adalah 17 - 21 tahun. Rata-rata kelompok pemilih ini adalah mereka yang sedang menempuh pendidikan tinggi dan pekerja muda, atau dengan kata lain lulus SMA.

Pemilih pemula merupakan pemilih potensial dengan jumlah pemilih yang cukup besar. Data BPS menyebutkan tidak kurang dari 15-20\% pemilih pada Pemilu 2014 adalah pemilih pemula. Jumlah pemilih pemula yang sangat besar ini mengundang partai politik dan politisi untuk mendulang perolehan suara dari mereka. Pemilih pemula juga dianggap menjadi "ladang emas " suara bagi keseluruhan partai politik. Siapapun itu yang bisa merebut perhatian kalangan ini tentu akan bisa merasakan keuntungannya, sebaliknya ketiadaan dukungan dari kalangan ini akan terasa cukup merugikan bagi target-target suara pemilihan yang ingin dicapai.

Pemilih pemula menjadi sasaran yang sangat strategis karena berbagai alasan yaitu pertama jumlah pemilih pemula dalam setiap pemilu cukup besar, kedua mereka adalah warga negara Indonesia yang baru pertama kalinya memberikan suara dalam Pemilu sehingga perlu diberikan arahan yang baik agar memiliki pemahaman yang baik terhadap proses demokrasi dan yang ketiga adalah karena mereka merupakan calon pemimpin masa depan sehingga dengan menggali dan mengetahui pandangan mereka tentang demokrasi dapat memberikan apa yang mereka butuhkan sebagai bekal masa depan.

Berdasarkan katagori umur, maka karakteristik yang dimiliki oleh pemilih pemula yaitu belum pernah memilih atau melakukan penentuan suara di dalam TPS, belum memiliki pengalaman memilih, memiliki antusiasme yang tinggi, kurang rasional, pemilih muda yang masih penuh gejolak dan semangat, memiliki rasa ingin tahu, mencoba, dan berpartisipasi dalam pemilu, meskipun kadang dengan berbagai latar belakang yang berbeda.

Selain itu pemilih pemula juga sering digambarkan melalui perilaku pemilih yang masih labil, pemilih yang memiliki pengetahuan politik yang relatif rendah, pemilih yang cenderung didominasi oleh kelompok (peer-group), pemilih yang melakukan pilihan karena aspek popularitas partai politik atau calon yang diusulkan partai politik dan pemilih yang datang ke tempat pemungutan suara (TPS) hanya sekadar untuk mendaftarkan atau menggugurkan haknya.

Affan Gaffar dalam penelitiannya melihat bahwa para pemilih muda khususnya pemilih pemula mempunyai perilaku khas yang mempunyai tendensi untuk tidak mengikuti arahan dan nasehat para pemimpin. Selain itu kaum muda memiliki kecenderungan untuk melawan dan

Jurnal Socius: Journal of Sociology Research and Education Vol. 6, No.1, Th. 2019 
memberontak, tetapi di sisi lain bisa jadi fenomena itu merupakan indikasi terjadinya perubahan sosial. (Nursal, 2004, hal. 88).

Dalam Pemilihan Gubernur dan Wakil Gubernur Jawa Timur Tahun 2018, data Penduduk Potensial Pemilih Pemilu (DP4) tercatat 30.747.387 jiwa. Terdiri pemilih perempuan 15.540.694 dan laki-laki sebanyak 15.206.693. Dan dari jumlah tersebut sebesar $6,2 \%$ nya adalah pemilih pemula yaitu sekitar 1.863 .770 pemilih pemula.

Di Kabupaten Ngawi, jumlah pemilih pemula yang akan mengikuti Pemilihan Gubernur dan Wakil Gubernur Jawa Timur Tahun 2018 menurut data dari KPU Kabupaten Ngawi adalah sebesar 59.544 pemilih. Adapun jumlah pemilih pemula dalam Pemilihan Gubernur dan Wakil Gubernur Jawa Timur Tahun 2018 di Kabupaten Ngawi adalah sebagai berikut :

Tabel 1. Daftar Pemilih Pemula dalam Pemilihan Gubernur dan Wakil Gubernur Jawa Timur Tahun 2018 di Kabupaten Ngawi

\begin{tabular}{|c|c|c|c|c|}
\hline \multirow{2}{*}{ No } & \multirow{2}{*}{ Kecamatan } & \multicolumn{2}{|c|}{ Pemilih Pemula } & \multirow[b]{2}{*}{ Total } \\
\hline & & $\mathbf{L}$ & $\mathbf{P}$ & \\
\hline 1 & Bringin & 964 & 964 & 1.928 \\
\hline 2 & Geneng & 1.663 & 1.674 & 3.337 \\
\hline 3 & Gerih & 1.188 & 1.134 & 2.322 \\
\hline 4 & Jogorogo & 1.451 & 1.524 & 2.975 \\
\hline 5 & Karanganyar & 905 & 860 & 1.765 \\
\hline 6 & Karangjati & 1.487 & 1.472 & 2.959 \\
\hline 7 & Kasreman & 787 & 732 & 1.519 \\
\hline 8 & Kedunggalar & 2.526 & 2.438 & 4.964 \\
\hline 9 & Kendal & 1.732 & 1.691 & 3.423 \\
\hline 10 & Kwadungan & 781 & 801 & 1.582 \\
\hline 11 & Mantingan & 1.328 & 1.341 & 2.669 \\
\hline 12 & Ngawi & 2.839 & 2.906 & 5.745 \\
\hline 13 & Ngrambe & 1.657 & 1.829 & 3.486 \\
\hline 14 & Padas & 1.003 & 1.008 & 2.011 \\
\hline 15 & Pangkur & 856 & 878 & 1.734 \\
\hline 16 & Paron & 3.187 & 3.163 & 6.350 \\
\hline 17 & Pitu & 952 & 923 & 1.875 \\
\hline 18 & Sine & 1.645 & 1.701 & 3.346 \\
\hline 19 & Widodaren & 2.790 & 2.764 & 5.554 \\
\hline & Total & 29.741 & 29.803 & 59.544 \\
\hline
\end{tabular}

Sumber: Data KPU Kabupaten Ngawi

Berbeda dengan jumlah pemilih pemula dari pemilihan sebelumnya yang hanya sekitar 12.127 pemilih, pada pemilihan Gubernur dan Wakil Gubernur Jawa Timur Tahun 2018 ini terdapat peningkatan pemilih pemula yang cukup besar yaitu hampir sekitar 5 kali dari jumlah sebelumnya. Dengan jumlah pemilih sebesar 749.755 pemilih dan jumlah pemilih pemula sekitar 7,94\% atau sekitar 59.544 pemilih menjadikan pemilih pemula merupakan pemilih potensial yang dibutuhkan suaranya bagi kandidat ataupun partai politik. Jumlah pemilih pemula yang besar dan emosi yang belum stabil membuat pemilih pemula rawan menjadi rebutan partai politik dan figur-figur yang bertarung dalam pemilu maupun pemilukada.

Pemilih pemula merupakan segmen masyarakat pemilih yang memiliki kekhasan sendiri dibandingkan dengan segmentasi masyarakat lainnya. Selain memiliki perilaku yang masih dianggap labil dan cenderung mengikuti kelompok, Emosi pemilih pemula yang labil

Jurnal Socius: Journal of Sociology Research and Education Vol. 6, No.1, Th. 2019 
seringkali membuat mereka memilih hanya berdasarkan hubungan emosional. Misalnya, karena orang tua mereka memilih partai A atau calon A maka mereka akan cenderung mengikuti pilihan orang tua mereka. Selain pengaruh orang tua, pilihan pemilih pemula juga dapat diintervensi oleh teman, keluarga, maupun iklan politik. Pemilih pemula sering kali lebih cenderung memilih partai-partai besar dan mapan. Ini karena mereka sudah familiar dengan partai tersebut dan enggan mengenal partai yang lain. Mereka juga cenderung memilih figurfigur yang familiar dengan mereka. Misalkan para tokoh yang sering menjadi bahan perbincangan di lingkungan mereka baik di sekolah maupun di masyarakat termasuk figurfigur yang yang sering muncul di televisi.

Hal ini sesuai dengan hasil penelitian dari Hevi Kurnia Hardini, Dosen Muda FISIP UMM terhadap Pemilih Pemula yang menjelaskan tentang perilaku pemilih pemula diantaranya adalah pemilih pemula lebih menyukai hal-hal yang mudah dan sederhana untuk dimengerti salah satu bentuknya adalah sikap memilih partai lama karena dianggap gampang. Selain itu di era globalisasi, penggunaan media internet termasuk media sosial merupakan sarana penyampai informasi yang begitu hebat khususnya di kalangan generasi muda. Menurut survei dari Lembaga Ilmu Pengetahuan Indonesia (LIPI) menunjukkan bahwa 60,6\% generasi $\mathrm{Z}$ atau anak muda kelahiran 1995-2005 mengakses berita terkait politik melalui media sosial. Akan tetapi terkadang informasi yang disampaikan tidak semuanya benar, bahkan banyak yang masuk dalam kategori berita bohong atau hoax. Hal ini tentunya dapat menyebabkan kebingungan di kalangan generasi muda yang merupakan pengguna media sosial aktif terbanyak saat ini dalam kapasitasnya sebagai pemilih pemula.

Untuk mengantisipasi kekhasan yang dimiliki oleh pemilih pemula agar tidak menjadi pasar potensial bagi partai atau kandidat untuk memperoleh suara dan agar pemilih pemula tidak terbujuk berita hoax dan berita bohong maka perlu dilakukan sosialisasi politik yang tepat yang sesuai dengan karakteristik pemilih pemula. Dengan demikian diharapkan mereka bisa menjadi pemilih yang cerdas yang memberikan suara secara rasional dan tepat dalam menentukan preferensi politiknya. Pemilih yang cerdas selain harus mengetahui visi, misi dan program dari pasangan calon juga harus mengenali riwayat hidup dari pasangan calon. Jika sudah mengetahui semuanya maka pemilih dapat memastikan siapa pasangan calon yang akan dipilihnya kemudian memastikan memberikan suara secara benar. Karena satu suara sangat berharga, One Person One Vote One Value.

Pemilih adalah warga negara yang mesti difasilitasi dengan baik untuk menggunakan hak pilihnya oleh penyelenggara pemilu. Dalam menjatuhkan pilihan, idealnya pemilih menggunakan kalkulasi yang rasional dan ilmiah dengan berlandaskan pada pengetahuan (knowledge), kesadaran (awareness) dan rasa tanggung jawab (responsibility) untuk membangun bangsa dan negara. Agar masyarakat menjadi pemilih yang rasional dan ilmiah serta sukarela, mandiri dan cerdas maka perlu diberi pengetahuan dan ditumbuhkan kesadaran politiknya. Disinilah pentingnya penyelenggaraan sosialisasi politik agar kualitas hasil pemilu juga dapat dipertanggungjawabkan.

Selain itu KPU juga menyebutkan bahwa sosialisasi politik bagi pemilih pemula bertujuan membangun kesadaran dan pemikiran kritis para pemilih muda untuk memilih dan berpartisipasi menyelenggarakan pemilu yang bersih dan anti politik uang lewat pendidikan politik, memberi informasi terkait prosedur memilih (bagaimana cara memilih, bagaimana memastikan diri terdaftar di Daftar Pemilih Tetap, bagaimana cara mengecek rekam jejak caleg, dan lain sebagainya), membuka wawasan pemilih pemula tentang berbagai isu kepemiluan seperti e-government, peranan sosial media dalam politik dan pemilu, pelanggaran pemilu, politik masuk kampus, dan daftar pemilih tetap.

Sebagai agen sosialisasi politik, KPU untuk meningkatkan partisipasi pemilih pemula dalam menggunakan hak pilihnya salah satu cara yang dapat ditempuh adalah dengan membangkitkan minat terhadap pemilihan umum. Penentuan program, strategi, penggunaan

Jurnal Socius: Journal of Sociology Research and Education Vol. 6, No.1, Th. 2019 
metode dan media yang sesuai dengan karakteristik generasi muda diperlukan KPU dalam melakukan sosialisasi tata cara pemilihan umum. Sehingga generasi muda tidak hanya menggunakan hak pilihnya tetapi juga memiliki sejumlah pertimbangan dan alasan untuk memberikan suaranya pada partai atau calon yang dianggap tepat untuk dipilih.

Strategi merupakan rencana jangka panjang yang diikuti oleh tindakan yang ditujukan untuk mencapai tujuan tertentu yang umumnya adalah kemenangan. Definisi strategi pertama yang dikemukakan oleh Chandler menyebutkan bahwa strategi adalah penetapan dari tujuan dan sasaran jangka panjang dari suatu organisasi serta penggunaan serangkaian tindakan dan alokasi sumber daya untuk mencapai tindakan tersebut. (Salusu, 2015, hal. 64)

Scroder menyebutkan bahwa strategi politik secara umum ada dua macam yaitu strategi ofensif (menyerang) dan strategi defensif (bertahan). Sedangkan menurut Newman dan Seth menyebutkan terdapat empat macam jenis stategi yaitu strategi penguatan, strategi rasionalisasi, strategi bujukan dan strategi konfrontasi

Penggunaan strategi yang tepat tentunya akan memudahkan KPU Kabupaten Ngawi untuk mencapai tujuan dari sosialisasi yang dilaksanakan. Dari beberapa pendapat dan jenis strategi diatas, strategi yang digunakan oleh KPU Kabupaten Ngawi dalam Pemilihan Gubernur dan Wakil Gubernur Jawa Timur Tahun 2018 diantaranya adalah strategi menyerang dengan gencar melakukan sosialisasi baik itu secara langsung maupun tidak langsung, strategi bujukan dengan mengadakan pendekatan kepada masyarakat lewat berbagai macam kegiatan yang menarik dan atraktif dan strategi penguatan kelembagaan dengan peningkatan kualitas SDM serta kerja sama dengan berbagai pihak yang terkait dalam pemilihan.

\section{Metodologi Penelitian}

Penelitian ini menggunakan pendekatan kualitatif deskriptif berupa studi kasus dimana peneliti mengembangkan analisa mendalam terhadap suatu kasus seperti suatu program, peristiwa, aktivitas, proses, atau sekelompok individu. Kasus-kasus dibatasi oleh waktu dan aktivitas, dan peneliti mengumpulkan informasi secara lengkap dengan menggunakan berbagai prosedur pengumpulan data berdasarkan waktu yang telah ditentukan (Stake dalam Creswell 2013, h.19)

Sebagai upaya untuk memperoleh data yang mendalam dan akurat maka dalam proses pengumpulan data, peneliti menitikberatkan pada proses wawancara mendalam terhadap informan yang ditentukan secara purposive sampling.

Demi akurasi data dan informasinya peneliti melakukan validitas data menggunakan teknik triangulasi data. Triangulasi adalah teknik pemeriksaan keabsahan data yang memanfaatkan sesuatu yang lain diluar data itu untuk keperluan pengecekan atau sebagai pembanding terhadap data itu (Moleong, 2005). Triangulasi dengan sumber yang dilaksanakan pada penelitian ini yaitu dengan melakukan wawancara beberapa kali pada informan yang berbeda untuk membandingkan apakah informasi yang diberikan oleh informan pertama dapat dipercaya atau tidak serta membandingkan hasil wawancara dengan isi dokumen yang berkaitan.

Proses wawancara dilakukan terhadap informan yaitu pihak-pihak yang berkaitan dengan strategi sosialisasi politik yang dilakukan oleh KPU Kabupaten Ngawi membentuk pemilih pemula yang cerdas dalam Pemilihan Gubernur dan Wakil Gubernur Jawa Timur tahun 2018 yaitu Anggota KPU Kabupaten Ngawi Divisi Partisipasi Masyarakat dan SDM, Sekretaris KPU Kabupaten Ngawi, Panitia Pemilihan Kecamatan, Panitia Pemungutan Suara, Relawan Demokrasi, Tokoh Masyarakat, Tokoh Akademis dan Pemilih Pemula. 


\section{Hasil Dan Pembahasan}

Strategi merupakan rencana jangka panjang yang diikuti oleh tindakan yang ditujukan untuk mencapai tujuan tertentu yang umumnya adalah kemenangan. Definisi strategi pertama yang dikemukakan oleh Chandler (1966) menyebutkan bahwa strategi adalah penetapan dari tujuan dan sasaran jangka panjang dari suatu organisasi serta penggunaan serangkaian tindakan dan alokasi sumber daya untuk mencapai tindakan tersebut. (Salusu, 2015, hal. 64). Namun istilah strategi tersebut berkembang pada bidang lain seperti strategi bisnis, strategi pengawasan dan strategi politik. Scroder (2010, 26-27) menyatakan bahwa strategi politik adalah strategi yang digunakan untuk merealisasikan cita-cita politik, seperti sosialisasi pemberlakuan peraturan baru ataupun pembentukan suatu struktur baru dalam administrasi pemerintahan. Strategi politik penting bukan hanya untuk partai politik dan pemerintah saja, semua organisasi yang aktif dalam kegiatan politik juga dapat menggunakan strategi politik tersebut. Organisasi dapat menggunakan strategi politik untuk mengkampanyekan dan mendorong kebijakan-kebijakan yang mengarah kepada perubahan masyarakat yang lebih baik.

Secara umum ada dua jenis strategi politik yang dapat digunakan untuk mengkampanyekan dan mensosialisasikan visi, misi, program serta tujuan organisasi, yaitu Strategi ofensif (menyerang), dimana suatu organisasi ingin melaksanakan sebuah program harus menjual atau menampilkan perbedaan terhadap keadaan sebelumnya dan menampilkan manfaat yang diharapkan dari kebijakan atau program tersebut serta strategi defensif (bertahan) yang akan digunakan jika organisasi ingin mempertahankan mayoritasnya atau jika pangsa pasar ingin dipertahankan. Untuk melaksanakan kedua strategi tersebut, Scroder menyatakan bahwa partai politik ataupun organisasi harus menentukan kelompok-kelompok target secara mendetail untuk meraih hasil yang maksimal dan menekan tercecernya informasi yang hendak disampaikan. Setelah menentukan kelompok target, partai politik ataupun organisasi perlu melakukan positioning

Menurut Baines dalam Nursal $(2004,153)$ bahwa proses positioning adalah menggambarkan kandidat atau partai terhadap segmen pemilih yang relevan. Dengan gambaran itu para pemilih dapat dibujuk untuk memilih kandidat atau partai tertentu untuk mengalihkan dukungan dari pihak lain ke pihak sendiri. Dalam kegiatan sosialisasi politik ini, positioning diperlukan untuk menggambarkan apa dan bagaimana pemilu yang baik dan berkualitas terhadap segmen pemilih yang relevan dalam hal ini adalah pemilih pemula. Dengan gambaran tersebut para pemilih dapat dibujuk untuk ikut berpartisipasi dalam kegiatan pemilihan dan tidak golput. Empat pilihan strategi positioning menurut Newman dan Shet dalam Nursal $(2014,159)$ diantaranya adalah Strategi Penguatan (Reinforcement Strategy), Strategi Rasionalisasi (Rationalization Strategy), Strategi Bujukan (Inducement Strategy) dan Strategi Konfrontasi (Strategi Konfrontasi). Sosialisasi politik merupakan suatu proses bagaimana memperkenalkan sistem politik pada seseorang dan bagaimana orang tersebut menentukan tanggapan serta reaksi-reaksinya terhadap gejala politik. (Michael Rush dan Philip Althoff, 2002, hal. 22). Ada dua hal yang perlu diperhatikan mengenai proses sosialisasi politik. Yang pertama adalah sosialisasi itu berjalan terus menerus selama hidup seseorang. Kedua, sosialisasi politik dapat berwujud transmisi dan pengajaran yang langsung maupun tak langsung. (Mas'oed, 1997, hal. 34) Strategi sosialisasi politik untuk membentuk pemilih pemula yang cerdas dalam
pemilihan Gubernur dan Wakil Gubernur Jawa Timur Tahun 2018

Pemilih pemula sering digambarkan dengan perilaku pemilih yang masih labil dan pemilih yang memiliki tingkat pengetahuan yang masih rendah. Selain itu pemilih pemula juga merupakan pemilih yang terkadang suka ikut-ikutan, baik itu ikut orang tua ataupun teman-

Jurnal Socius: Journal of Sociology Research and Education Vol. 6, No.1, Th. 2019 
teman. Selain jumlah pemilihnya cukup besar, pemilih pemula juga cukup penting karena mereka adalah warga negara yang baru pertama kali menggunakan hak pilihnya sehingga perlu diberikan arahan yang baik agar mereka memiliki pemahaman yang baik terhadap proses demokrasi. Dengan adanya sosialisasi mereka diharapkan mempunyai prinsip sendiri dalam memilih.

Pemilih cerdas artinya pemilih yang rasional, obyektif dan memilih berdasarkan penilaian dirinya, bukan atas dorongan uang, suku dan faktor ikut-ikut teman atau orang tua. Adanya peningkatan pengetahuan diharapkan membuat pemilih menjadi cerdas sehingga dapat memahami bahwa pilihannya pada peserta pemilu (Presiden, Gubernur, Bupati, calon anggota DPR, DPRD maupun DPD) mempunyai rekam jejak yang baik dan pantas untuk dipilih. Berdasarkan Modul dari KPU RI yang berjudul Memilih Dengan Cermat dan Cerdas, pemilih yang cerdas haruslah mengetahui visi, misi dan program pasangan calon, mengenali riwayat hidup calon dan partai politiknya, memastikan pilihan serta memastikan memberikan suara secara benar.

KPU Kabupaten Ngawi sebagai agen sosialisasi melaksanakan kegiatan sosialisasi tentang apa, bagaimana, kapan dan dimana mengenai seluruh tahapan tata cara kepemiluan kepada seluruh sasaran kepentingan pemilu yang demokratis. Penggunaan strategi yang tepat merupakan hal terpenting yang harus dilakukan oleh KPU Kabupaten Ngawi agar tujuan untuk melakukan sosialisasi tercapai dan memberikan hasil yang maksimal.

Menggunakan konsep Candler, Scroder serta Newman Seth, bahwa Strategi KPU Kabupaten Ngawi dalam melaksanakan sosialisasi politik untuk membentuk pemilih pemula yang cerdas adalah sebagai berikut:

\section{Formulasi strategi dan penyusunan rencana jangka panjang}

Tahapan perencanaan yang dilakukan oleh KPU Kabupaten Ngawi dalam kegiatan sosialisasi ini selain merencanakan tujuan dan sasaran sosialisasi juga merencanakan program kegiatan sosialisasi, metode pelaksanaan sosialisasi dan anggaran untuk melaksanakan sosialisasi. Selain itu juga mempertimbangkan koordinasi baik itu dengan pihak internal, penyelenggara pemilu di tingkat bawah juga koordinasi dengan pihak eksternal.

Dengan adanya peraturan dari Komisi Pemilihan Umum Nomor 8 Tahun 2017 tentang Sosialisasi, Pendidikan Pemilih dan Partisipasi Masyarakat Dalam Pemilihan Gubernur dan Wakil Gubernur, Bupati dan Wakil Bupati, dan / atau Walikota dan Wakil Walikota yang terbaru membuat proses perencanaan semakin mudah. Karena di dalam peraturan tersebut dijelaskan dengan terinci mengenai segala kegiatan sosialisasi baik itu tujuannya, sasarannya, metode pelaksanaannya, materinya dan lain sebagainya.

Tujuan dari pelaksanaan sosialisasi adalah untuk menyebarluaskan informasi mengenai tahapan, jadwal dan program pemilihan. Meningkatkan pengetahuan, pemahaman dan kesadaran masyarakat tentang hak dan kewajiban dalam pemilihan serta meningkatkan partisipasi pemilih dalam pemilihan.

Sedangkan sasaran dalam kegiatan sosialisasi meliputi pemilih yang berbasis keluarga, pemilih pemula, pemilih muda, pemilih perempuan, pemilih penyandang disabilitas, pemilih berkebutuhan khusus, kaum marginal, komunitas, keagamaan, relawan demokrasi dan warga internet (netizen). Selain itu sasaran sosialisasi juga meliputi masyarakat umum, media massa, partai politik, pengawas, pemantau pemilihan dalam negeri dan pemantau pemilihan asing, organisasi kemasyarakatan, masyarakat adat dan instansi pemerintah.

Bentuk-bentuk program sosialisasi yang dilaksanakan oleh KPU Kabupaten Ngawi mengacu pada anggaran serta petunjuk teknis yang diberikan oleh KPU Propinsi Jawa Timur. Karena lingkup pemilihan adalah pemilihan Gubernur dan Wakil Gubernur Jawa Timur Sehingga perencanaan anggaran maupun kegiatan sudah diatur oleh KPU Propinsi Jawa Timur. Program sosialisasi yang dilakukan adalah seminar sosialisasi, tatap muka, sosialisasi

Jurnal Socius: Journal of Sociology Research and Education Vol. 6, No.1, Th. 2019 
pemanfaatan teknologi, iklan di media cetak dan elektronik, sosialisasi gelar seni budaya, pemasangan poster, baliho, umbul-umbul dan panflet, mobil sosialisasi, media center, pembentukan relawan demokrasi, jalan sehat dan sosialisasi berbasis komunitas. Khusus untuk sosialisasi ke pemilih pemula, program unggulan yang dilakukan oleh KPU kabupaten Ngawi adalah melaksanakan kelas pemilu, menjadi pembina upacara di sekolah-sekolah serta sosialisasi tatap muka dengan mengundang perwakilan dari sekolah-sekolah.

\section{Pemilihan tindakan dalam kegiatan sosialisasi}

Pemilihan tindakan yang dilakukan oleh KPU Kabupaten Ngawi dalam melaksanakan kegiatan sosialisasi menggunakan dua strategi, yaitu:

\section{Strategi menyerang}

Strategi menyerang yang dilaksanakan oleh KPU Kabupaten Ngawi adalah dengan gencar melaksanakan sosialisasi langsung dan sosialisasi tidak langsung selama tahapan Pemilihan Gubernur dan Wakil Gubernur Jawa Timur Tahun 2018.

\section{Sosialisasi Langsung}

Proses sosialisasi politik menurut Gabriel Almond mencakup dua hal yaitu pertama adalah sosialisasi itu berjalan terus menerus selama hidup seseorang. Kedua, sosialisasi politik dapat berwujud transmisi dan pengajaran yang langsung maupun tak langsung.

Dalam konteks pemilihan Gubernur dan Wakil Gubernur Jawa Timur Tahun 2018 ini yang dimaksudkan peneliti sesuai dengan pendapat Gabriel Almond tersebut adalah bahwa sosialisasi dilakukan selama tahapan pelaksanaan Pemilihan Gubernur dan Wakil Gubernur Jawa Timur ini berlangsung. Adapun sesuai dengan tahapan yang sudah dituliskan oleh peneliti pada bab sebelumnya, pelaksanaan sosialisasi dilakukan pada tanggal 14 Juni 2017 sampai dengan 23 Juni 2018.

Sosialisasi langsung dalam pemilihan Gubernur dan Wakil Gubernur Jawa Timur dilakukan melalui sosialisasi tatap muka baik itu lewat gelar seni budaya, sosialisasi dengan komunitas maupun kelas pemilu. Sosialisasi secara langsung bukanlah proses yang dilaksanakan secara sepihak, ada komunikasi antara pihak yang melakukan sosialisasi dengan pihak yang disosialisasi. Dalam sosialisasi langsung yang perlu diperhatikan adalah bagaimana bahasa yang digunakan serta materi yang disosialisasikan. Penggunaan bahasa yang baik dan benar serta sederhana memudahkan peserta sosialisasi untuk memahami apa yang ingin disampaikan oleh pihak yang melaksanakan sosialisasi.

Selain itu materi yang disampaikan juga harus menarik agar peserta tidak merasakan kebosanan. Untuk menjadikan pemilih pemula yang cerdas, KPU kabupaten Ngawi melaksanakan program sosialisasi secara langsung dengan mendatangi sekolah-sekolah atau yang dikenal dengan kelas pemilu. Di dalam kelas pemilu KPU selaku penyelenggara pemilu lebih banyak memberikan materi seperti halnya pelajaran di sekolah. Jadi KPU harus mempunyai rancangan pembelajaran apa dan bagaimana yang akan di berikan ke siswa.

Kelas pemilu bukan hanya memberikan informasi umum yang disampaikan tetapi lebih ke pendidikan kepemiluannya yang diberikan. Di kelas KPU bisa melakukan apa saja tidak hanya ceramah, tapi bisa berdiskusi mengenai isu terkini, kemudian juga bisa menampung aspirasi dari para siswa. Jika ingin memilih pemimpin, idealnya yang menurut mereka seperti apa dan memang kelas pemilu ditujukan kepada pemilih pemula karena pemilih pemula itu dianggap masih bersih, belum terkontaminasi unsur kepentingan dari manapun, mempunyai idealisame yang bagus tentang kriteria pemimpin yang mereka inginkan.

Itulah mengapa kelas pemilu menjadi unggulan. Dari kelas pemilu bisa memberikan masukan-masukan bagaimana pemilu yang bagus, bagaimana seharusnya menjadi pemilih. Jangan hanya karena diberi amplop, atau janji-janji kampanye yang manis mereka menjadi tergiur. Sehingga di kelas pemilu itulah KPU bisa memberikan edukasi yang tepat. 
Kegiatan kelas pemilu memang lebih bisa memberikan pemahaman kepada pemilih pemula tentang apa dan bagaimana pemilu itu serta bagaimana menjadi pemilih yang cerdas. Akan tetapi dengan jumlah sekolah sebanyak 77 sekolah yang tersebar di seluruh wilayah Kabupaten Ngawi tidak memungkinkan petugas KPU Kabupaten Ngawi untuk mendatangi satu persatu dikarenakan jumlah personil, biaya dan waktu yang terbatas,

Dengan kendala SDM, biaya dan waktu tersebut tentunya pelaksanaan kelas pemilu menjadi kurang efektif dan tidak bisa meraih jumlah pemilih pemula secara banyak. Untuk menjangkau jumlah pemilih pemula lainnya di banyak sekolahan, KPU Kabupaten Ngawi berencana untuk meminta kepada DPRD kemudian ke lembaga pendidikan agar memasukkan kurikulum tentang kepemiluan di sekolahan.

Selain melaksanakan kelas pemilu, KPU Kabupaten Ngawi juga melakukan sosialisasi tatap muka dengan mengundang perwakilan guru dan murid dari sekolah, universitas, organisasi masyarakat yang ada pemilih pemulanya. Dalam sosialisasi tatap muka tersebut selain dijelaskan mengenai pilkada dan tahapannya juga diadakan simulasi mengenai tata cara pencoblosan. Akan tetapi sosialisasi tatap muka untuk pemilih pemula jika hanya diadakan 1 (satu) kali tentu kurang bisa mencapai target tujuan sosialisasi.

Selain KPU kabupaten yang melaksanakan sosialisasi ke pemilih pemula, penyelenggara di tingkat bawah seperti PPK dan PPS juga harus ikut melaksanakan sosialisasi ke pemilih pemula tersebut. KPU Kabupaten Ngawi mewajibkan PPK yang di daerahnya ada sekolah harus melaksanakan sosialisasi ke pemilih pemula. Jika tiap-tiap PPK dan PPS melakukan sosialisasi ke pemilih pemula baik itu ke sekolah-sekolah yang ada di masingmasing kecamatan atau di desa-desa wilayahnya tentu kerja KPU Kabupaten Ngawi untuk melakukan sosialisasi ke pemilih pemula semakin ringan.

Akan tetapi, dari hasil penelitian tidak semua PPK maupun PPS melaksanakan sosialisasi ke pemilih pemula. Kebanyakan dari mereka hanya melaksanakan sosialisasi di arisan RT maupun pengajian ibu-ibu tanpa melibatkan pemilih pemula. Padahal banyak juga pemilih pemula yang tidak mendapatkan sosialisasi di bangku sekolah-sekolah.

Kreatifitas dan inovasi juga harus terus dikembangkan oleh penyelenggara pemilu untuk mewujudkan suatu kegiatan yang menarik dan tidak membosankan. Karakteristik pemilih pemula yang rasa ingin tahunya besar serta tidak menyukai text book dengan duduk berlama lama di meja tentunya perlu untuk KPU mengembangkan suatu produk sosialisasi yang lain dari biasanya. Contohnya kegiatan outbound, games, lomba seni atau lainnya sebagainya. Sehingga bentuk -bentuk seperti itu justru lebih efektif dan inovatif. Sedangkan yang dilakukan oleh KPU Kabupaten Ngawi selama ini kan hanya mengundang, datang dan hanya penyampaian materi saja. Bentuknya monoton kurang inovasi.

\section{Sosialisasi Tidak Langsung}

Sosialisasi tidak langsung dilakukan lewat pemasangan poster, spanduk, baliho kemudian lewat media online seperti website, facebook, twitter, instagram, whatsapp group dengan membuat pesan bergambar atau meme pemilu untuk di share ke group atau dijadikan status. Selain media sosial juga dilakukan pemasangan Iklan radio, kerjasama dengan radio, talkshow menjadi narasumber di radio suara ngawi, iklan di media cetak dan lain sebagainya. KPU juga menyarankan agar semua penyelenggara untuk aktif update status mengenai kegiatan pemilu dan memahami mengenai tahapan sehingga bisa mensosialisasikan ke masyarakat.

Media massa baik itu cetak maupun elektronik masih menjadi salah satu wahana yang efektif sebagai penyampai informasi kepada pemilih. Media massa mampu menjangkau pelbagai lapisan di masyarakat serta mempunyai fungsi yang persuasif yang mampu membentuk kesadaran pemilih. Media mampu mempengaruhi opini pemilih atas berbagai persoalan yang sedang berkembang di masyarakat. 
Media massa dapat menjangkau audien yang luas dan karenanya dapat menghasilkan pemilih atau opini publik yang lebih besar dibandingkan dengan komunikasi ataupun sosialisasi tatap muka secara langsung.

\section{Strategi bujukan}

Strategi bujukan yang dilakukan oleh KPU kabupaten Ngawi dalam melakukan kegiatan sosialisasi politik pemilihan Gubernur dan wakil gubernur jawa timur tahun 2018 adalah:

1. Melakukan pendekatan kepada masyarakat melakui berbagai kegiatan

KPU Kabupaten Ngawi melakukan pendekatan kepada masyarakat melalui kegiatan yang menarik minat dan antusiasme dari masyarakat. Yaitu Gelar Seni Budaya, Jalan Sehat Guyub Rukun, Sosialisasi dengan komunitas mancing bareng, Sosialisasi dengan komunitas ngontel bareng dan lain sebagainya.

2. Debat pasangan calon Gubernur dan Wakil Gubernur Jawa Timur Tahun 2018

Debat pasangan Gubernur dan Wakil Gubernur Jawa Timur dilakukan 3 (tiga) kali dan disiarkan secara langsung di televisi. Dalam debat ini masing-masing pasangan calon memaparkan visi misi mereka. Rhenald Kasali ( (Nursal, 2004) membagi manusia dalam 5 segmen yaitu masa transisi, masa pembentukan keluarga, masa peningkatan karier atau pekerjaan, masa kemapanan dan masa persiapan pensiun. Masa transisi adalah usia 17 -23 tahun, dimana sebagian segmen ini masih dalam pendidikan formal. Yang lainnya sudah bekerja tetapi cenderung masih berpenghasilan rendah dan sebagian besar penghasilannya habis dikonsumsi untuk diri sendiri. Dari beberapa penelitian, segmen ini cenderung mengekspresikan sikap yang berbeda-beda dengan segmen lainnya, termasuk penolakan untuk memilih partai-partai tertentu karena paksaan, baik paksaaan yang bersifat samar ataupun nyata dari orang-orang sekitarnya.

Usia transisi hampir berdekatan dengan kategori usia pemilih pemula, dimana karakteristik pemilih pemula menurut Affan Gaffar adalah mempunyai perilaku yang cenderung tidak mengikuti arahan atau nasehat para pemimpin dan memiliki kecenderungan untuk melawan dan memberontak.

Hal ini terlihat dalam pemilihan gubernur dan wakil Gubernur Jawa Timur Tahun 2018, dari beberapa pemilih pemula yang diwawancarai oleh peneliti mereka mengatakan bahwa mereka memilih calon Gubernur dan Wakil Gubernur berdasarkan dengan visi dan misi pasangan calon, tidak mengikuti anjuran dari orang tua maupun teman. Pemilih cerdas adalah pemilih yang rasional, obyektif dan memilih berdasarkan penilaian dirinya, bukan atas dorongan uang, suku dan faktor ikut-ikut teman atau orang tua.

\section{Alokasi penggunaan sumber daya organisasi}

Alokasi penggunaan sumber daya organisasi dilakukan dengan menggunakan strategi penguatan. Adapun strategi penguatan yang dilakukan oleh KPU Kabupaten Ngawi adalah:

a. Meningkatkan kapasitas dan kualitas penyelenggara pemilihan

Sinergitas antara KPU, KPU Provinsi, KPU Kabupaten/Kota, PPK, PPS dan KPPS dalam penyelenggaraan merupakan suatu hal yang wajib sehingga diharapkan dapat menghasilkan kepala daerah yang diinginkan oleh rakyat, yaitu kepala daerah yang berintegritas, kredibel dan akuntabel. Selain itu penyelenggaraan Pilkada yang bersifat langsung, umum, bebas, rahasia, jujur dan adil hanya dapat terwujud apabila penyelenggara mempunyai integritas yang tinggi serta memahami segala tahapan dalam pemilihan. Untuk peningkatan kualitas dan kapasitas penyelenggara pemilihan, KPU Kabupaten Ngawi melakukan bimtek terhadap 
semua jajaran adhoc untuk setiap tahapan. Selain itu juga melakukan kajian bersama terhadap peraturan-peraturan yang ada, melakukan sosialisasi baik kepada peserta pemilu maupun masyarakat, melakukan evaluasi dalam setiap tahapan serta berkoordinasi dengan bawaslu berkenaan dengan tahapan yang sedang berjalan.

b. Memperkuat komunikasi dan keterbukaan informasi tentang pemilihan.

Komunikasi adalah salah satu kemampuan institusional yang paling penting untuk dimiliki setiap lembaga publik, termasuk diantaranya penyelenggara pemilu yaitu KPU, KPU Propinsi dan KPU Kabupaten/Kota. Komunikasi yang sifatnya memperkuat koordinasi menjadi salah satu kunci sukses dalam keberhasilan pelaksanaan tahapan pemilihan.

Komunikasi tidak hanya terbatas pada media saja. Komunikasi yang efektif juga harus dibangun dengan partisipasi aktif pihak yang berkaitan dengan pemilihan seperti partai politik, peserta pemilihan, organisasi masyarakat, pemilih dan instansi.

Perkembangan keterbukaan informasi publik dimulai dengan lahirnya UU No. 14 Tahun 2008 tentang Komisi Informasi Publik (KIP). Alasan yang mendasari lahirnya regulasi ini adalah bahwa informasi merupakan hak asasi manusia, keterbukaan informasi juga ditujukan untuk mengoptimalkan pengawasan publik dalam penyelenggaraan pemerintahan dan segala sesuatu yang berkaitan dengan kepentingan publik serta guna memberikan kepastian hukum bagi publik untuk mendapatkan informasi. (Kholilullah P, 2014, hal. 5-6)

Salah satu azas dalam penyelenggaraan pemilu adalah transparansi yaitu adanya akuntabilitas dalam penyelenggaraan pemilu sehingga kepercayaan publik dapat terbangun dengan baik. Cara-cara yang dilaksanakan oleh KPU Kabupaten Ngawi dalam rangka melaksanakan azas transparansi tersebut diantaranya adalah:

1. Membentuk PPID (Pejabat Pengelola Informasi dan Dokumentasi) yang bisa dimanfaatkan oleh masyarakat untuk permintaan data kepemiluan.

2. Aplikasi SIPARMAS yang mengupload semua kegiatan sosialisasi yang telah dilakukan oleh penyelenggara pemilihan

3. Aplikasi Kampanye yang berisi semua tentang seluk beluk kampanye mulai dari tim kampanye, pelaksana kampanye, Alat Peraga Kampanye, Laporan Dana Kampanye, Jadwal Kampanye, media sosial peserta pemilu dan lain sebagainya.

4. Rumah Pintar Pemilu berisi berbagai sarana untuk memberikan pengetahuan, pemahaman dan kesadaran dan inspirasi masyarakat tentang pentingnya pemilu dan demokrasi. Penyampaian tentang pemilu dan demokrasi tersebut dapat disampaikan melaui penayangan audio visual, ruang pamer, ruang simulasi dan ruang diskusi.

5. Media Center KPU

c. Meningkatkan kerjasama dengan stakeholders yang berkepentingan

Dalam pemilihan Gubernur dan Wakil Gubernur Jawa Timur Tahun 2018 ini KPU Kabupaten Ngawi selalu melakukan koordinasi dan bekerjasama dengan stakeholder internal maupun ekternal. Stakeholder internal dari KPU adalah penyelenggara pemilihan di tingkat bawah yaitu PPK, PPS, KPPS dan PPDP serta Bawaslu. Sedang eksternal stakeholder meliputi kepolisian, dispendukcapil, media, satpol pp, bakesbangpol, linmas, peserta pilkada, partai politik serta pemilih yang meliputi 11 segmen pemilih.

Kerjasama yang dilakukan oleh KPU kabupaten Ngawi untuk sosialisasi kepada pemilih pemula diantaranya :

1. Dengan sekolah-sekolah: mengadakan kelas pemilu serta mengadakan sosialisasi tatap muka dengan mengundang perwakilan guru dan murid, 
2. Universitas: melakukan KPU goes to campus, menjadi narasumber acara yang diadakan oleh universitas serta mengadakan sosialisasi tatap muka dengan mengundang perwakilan kampus.

3. Organisasi masyarakat: mengadakan sosialisasi tatap muka dengan mengundang perwakilan dari ormas serta menjadi narasumber jika diundang oleh ormas.

4. Bakesbangpol: mengundang KPU untuk menjadi narasumber kegiatan sosialisasi yang diadakan oleh Bakesbangpol di sekolah-sekolah.

\section{Kendala yang dihadapi dalam pelaksanaan sosialisasi politik}

Dalam setiap pelaksanaan kegiatan tentu tidak terlepas dari kendala dan hambatan. Adapun kendala yang ditemui oleh KPU Kabupaten Ngawi selama pelaksanaan kegiatan sosialisasi ini adalah :

1. Anggaran biaya

Dalam Pemilihan Gubernur dan Wakil Gubernur Jawa Timur Tahun 2018 anggaran yang diterima oleh masing-masing KPU Kabupaten/Kota tentu berbeda-beda tergantung jumlah kecamatan maupun desanya. Di dalam Rincian Anggaran Belanja yang sudah dikeluarkan oleh KPU Provinsi Jawa Timur selaku penanggung jawab kegiatan Pilgub sudah diatur mengenai besaran anggaran dan peruntukkan kegiatannya. KPU Kabupaten/Kota harus mengikuti petunjuk teknis mengenai kegiatan yang sudah dianggarkan oleh KPU provinsi dalam RAB tersebut. Kegiatan sosialisasi yang dilakukan oleh KPU Kabupaten Ngawi sesuai dengan petunjuk teknis yang sudah diberikan oleh KPU provinsi Jawa Timur. KPU Kabupaten Ngawi tidak bisa berkreasi dan berinovasi agar kegiatan sosialisasi tersebut bisa disesuaikan dengan situasi dan kondisi pemilih yang ada di Kabupaten Ngawi. Selain itu, untuk menjangkau jumlah pemilih pemula lainnya di banyak sekolahan tidak bisa dilaksanakan secara maksimal dikarenakan adanya keterbatasan anggaran. KPU tidak bisa memaksakan tim untuk berangkat tanpa ada adanya sarana dan prasarana serta koordinasi dengan masing-masing sekolah. Untuk itu KPU Kabupaten Ngawi berencana untuk meminta kepada DPRD kemudian ke lembaga pendidikan agar memasukkan kurikulum tentang kepamiluan di sekolahan-sekolahan.

2. Keterbatasan jumlah personil

Sesuai dengan surat edaran KPU bahwa jumlah personil di Kabupaten hanya sekitar 17 orang PNS, 5 komisioner dan 5 tenaga kontrak. Jumlah personil tersebut dibandingkan dengan banyaknya kegiatan tahapan yang berjalan kadang tidak mencukupi. Walaupun ada penambahan tenaga pendukung sebanyak 5 orang lagi tapi terkadang tidak cukup personil jika kegiatan sudah bertumpuk tumpuk. Selain itu luas wilayah Kabupaten Ngawi dan jumlah penduduk yang begitu besar juga menjadi salah satu faktor penghambat dalam melakukan sosialisasi.

3. Keterbatasan waktu

Sempitnya waktu dibanding dengan banyaknya kegiatan yang harus dilakukan membuat pekerjaan tidak akan terselaesaikan secara maksimal. Banyaknya kegiatan dalam setiap tahapan pemilihan terkadang membuat pelaksanaan satu kegiatan dengan kegiatan yang lainnya saling berbarengan, sehingga hal tersebut membuat prioritas kegiatan mana yang harus dielesaikan terlebih dahulu.

4. Cakupan wilayah yang luas

Luas suatu wilayah mempunyai pengaruh yang sangat besar terhadap setiap kegiatan yang akan dilakukan. Kabupaten Ngawi mempunyai luas wilayah sebesar $1.295,98 \mathrm{~km}^{2}$ ini terbagi ke dalam 19 kecamatan dan 217 desa. Dengan topografi wilayah ada yang berupa dataran tinggi dan tanah datar. Jumlah penduduk sekitar 829.899 jiwa, terdiri dari 405.796 penduduk laki-laki dan 424.103 penduduk perempuan. Dalam pelaksanaan pemilihan selalu melewati tahapan yang panjang. Setiap informasi dalam tahapan tersebut perlu diketahui 
oleh masyarakat sebagai calon pemilih. Sehingga pelaksanaan sosialisasi secara maksimal perlu dilakukan. Salah satunya adalah dengan melibatkan partisipasi masyarakat lewat metode pembentukan Relawan demokrasi atau biasa disebut dengan Relasi. Dalam pemilihan Gubernur dan Wakil Gubernur Jawa Timur Tahun 2018 ini KPU Kabupaten Ngawi merekrut 10 orang dari berbagai komunitas dan dan latar belakang sosial kemasyarakatan di Kabupaten Ngawi. Relawan demokrasi yang dibentuk oleh KPU Kabupaten Ngawi akan menjadi mitra penyelenggara di 19 Kecamatan dalam melaksanakan sosialisasi, khususnya anggota PPK yang membidangi sosialisasi dan akan melaksanakan sosialisasi pada 5 segmen utama yaitu masyarakat pinggiran, masyarakat difabel, pemilih dengan basis keagamaan, pemilih pemula maupun kaum perempuan. Pembentukan relawan demokrasi sangat bermanfaat untuk KPU, terutama membantu dalam hal peningkatan sosialisasi. Keberadaan Relawan Demokrasi dapat menjadi relasi yang memiliki tugas melakukan fasilitasi pendidikan pemilih kepada masyarakat. Akan tetapi menurut hasil penelitian di lapangan, relawan demokrasi yang berjumlah 10 orang tersebut dengan fokus kepada 5 segmen pemilih kurang maksimal dalam melakukan kegiatan sosialisasi. Karena tidak semua kecamatan akan terjangkau oleh relawan demokrasi. Akan lebih baik jika terdapat relawan demokrasi di masing-masing kecamatan yang melakukan sosialisasi ke semua segmen.

\section{Peningkatan Partisipasi Masyarakat Dalam Pemilihan Gubernur dan Wakil Gubernur Jawa Timur Tahun 2018}

Pemilihan Gubernur dan Wakil Gubernur Jawa Timur Tahun 2018 pada tanggl 27 Juni 2018 sudah selaesai dilaksanakan. Dari target partisipasi pemilih yang diharapkan oleh KPU Provinsi Jatim sebesar 77, $5 \%$, KPU Kabupaten Ngawi hanya bisa merealisasikan partisipasi pemilih sebesar 68,05\%. Partisipasi pemilihan Gubernur dan Wakil Gubernur Jawa Timur Tahun 2018 di Kabupaten Ngawi mengalami kenaikan jika dibandingkan dengan pemilihan gubernur sebelumnya pada tahun 2013 yang hanya mencapai partisipasi sebesar 58,23\%. Dari hasil pelaksanaan pemilihan Gubernur dan Wakil Gubernur Jawa Timur Tahun 2018 khususnya di Kabupaten Ngawi memang di luar perkiraan. Kabupaten Ngawi yang selama ini terkenal sebagai basis banteng merah dan di dukung oleh Bupati yang mengerahkan segenap daya upaya untuk memenangkan pasangan Drs. H. Saifullah Yusuf - Hj. Puti Guntur Soekarno, S.IP ternyata dari hasil penghitungan suara kalah dibandingkan pasangan Khofifah Indar Parawansa - Dr. Emil Elestianto Dardak, M.sc.

Berikut hasil penghitungan suara Pemilihan Gubernur dan Wakil Gubernur Jawa Timur Tahun di Kabupaten Ngawi :

Tabel 2. Rekapitulasi Hasil Penghitungan Suara Pemilihan Gubernur dan Wakil Gubernur Jawa Timur Tahun 2018 di Kabupaten Ngawi

\begin{tabular}{clcc}
\hline No & \multicolumn{1}{c}{ Pasangan Calon } & Perolehan Suara & Prosentase \\
\hline 1 & $\begin{array}{l}\text { Drs. H. Saifullah Yusuf - Hj. Puti } \\
\text { Guntur Soekarno, S.ip }\end{array}$ & 221.289 & $47,70 \%$ \\
\hline 2 & $\begin{array}{l}\text { Khofifah Indar Parawansa - Dr. } \\
\text { Emil Elestianto Dardak, M.sc. }\end{array}$ & 242.639 & $52,30 \%$ \\
\hline & & 463.928 & $100 \%$ \\
\hline
\end{tabular}

Kenaikan tingkat partisipasi ini tidak lepas dari strategi KPU Kabupaten Ngawi dalam melaksanakan kegiatan sosialisasi secara terus menerus. Sosialisasi yang dilaksanakan kepada pemilih pemula khususnya diharapkan akan membuat mereka mengerti dan memahami bahwa pemilu tidak hanya kampanye yang grudak gruduk atau saat mereka mencoblos saja, akan tetapi satu suara pemilih itu sangat berpengaruh terhadap kebijakan politik, ekonomi dan lain

Jurnal Socius: Journal of Sociology Research and Education Vol. 6, No.1, Th. 2019

ISSN: Online 2442-8663 - Print 2356-4180 
sebagainya. Mereka juga harus menjadi pemilih cerdas yang aktif ikut mengawal dan mengawasi pemerintah hasil pemilihan.

Pemilih sekarang sudah cerdas, dan seiring perkembangan teknologi pemilih pemula sekarang sudah tau baik itu tanggal pelaksanaan pemilihan, kandidatnya siapa, misi visinya apa baik itu melalui sosial media, TV ataupun media massa lainnya. Anak-anak dalam hal ini pemilih pemula adalah pelaku sosial media. Selain itu masyarakat sekarang juga cenderung melihat kompetensi dari calonnya bukan hanya dari partai mereka berasal.

\section{Penutup}

Adanya regulasi baru mengenai sosialisasi politik dalam pemilihan Gubernur dan Wakil Gubernur Jawa Timur Tahun 2018 ini lewat PKPU No. 8 Tahun 2017 tentang Sosialisasi, Pendidikan Pemilih dan Partisipasi Masyarakat dalam Pemilihan Gubernur dan Wakil Gubernur, Bupati dan Wakil Bupati, dan/atau Walikota dan Wakil Walikota yang memuat halhal baru dan lebih terperinci di dalam pelaksanaan sosialisasi membuat KPU provinsi ataupun Kabupaten/Kota lebih mudah untuk menentukan program dan sasaran sosialisasi. Dalam melakukan sosialisasi KPU Kabupaten Ngawi melakukan strategi menyerang dengan gencar melaksanakan sosialisasi baik secara langsung maupun tidak langsung. Selain itu juga melalui strategi bujukan dengan melakukan pendekatan kepada masyarakat melalui kegiatan yang menarik serta penayangan debat pasangan calon Gubernur dan Wakil Jawa Timur di televisi. Untuk memaksimalkan seluruh potensi sumber daya, strategi penguatan kelembagaan dilakukan lewat meningkatkan kapasitas dan kualitas penyelenggara pemilihan, meningkatkan kerja sama dengan stakeholder serta memperkuat komunikasi dan keterbukaan informasi tentang pemilihan. Tetapi, penyelenggara pemilihan di tingkat bawah seperti PPK dan PPS dalam melakukan sosialisasi khusus ke pemilih pemula masih belum terlaksana dengan baik. Sosialisasi hanya dilakukan lewat arisan RT ataupun pengajian ibu-ibu dan tidak mengkhususkan program sosialisasi ke pemilih pemula. Padahal banyak juga pemilih pemula yang tidak mendapat kesempatan mengikuti sosialisasi tatap muka langsung ataupun kelas pemilu oleh KPU Kabupaten Ngawi.

Selain itu, dengan jumlah sekolah menengah atas sebanyak 77 sekolah serta universitas yang tersebar di seluruh wilayah Kabupaten Ngawi tidak memungkinkan KPU untuk melakukan kelas pemilu ke semua sekolah dikarenakan faktor biaya, waktu dan tenaga yang terbatas. Pembentukan Relawan demokrasi yang dilakukan dengan melibatkan 10 orang personil untuk membantu KPU dalam melaksanakan sosialisasi di seluruh kecamatan di kabupaten Ngawi juga kurang efektif. Dengan personil yang berjumlah 10 sedangkan jumlah kecamatan 19 tidak membuat relawan demokrasi ini bisa memberikan sosialisasi ke semua lapisan masyarakat. Sosialisasi yang dilakukan oleh Relawan Demokrasi mencakup 5 segmen yaitu Pemilih pemula, Kelompok Agama, Kelompok Perempuan, Difabel, Kelompok Pinggiran, dan kelompok lainnya. Adanya peningkatan partisipasi masyarakat dalam Pemilihan Gubernur dan Wakil Gubernur Tahun 2018 ini tak lepas dari sosialisasi yang dilaksanakan oleh KPU beserta penyelenggara di tingkat bawahnya. Sosialisasi yang dilaksanakan oleh KPU Kabupaten Ngawi sudah maksimal akan tetapi hasilnya belum sesuai dengan yang diharapkan, hal ini dikarenakan dalam Pemilihan Gubernur dan Wakil Gubernur Jawa Timur Tahun 2015 seluruh rencana kegiatan dan anggaran dibuat oleh KPU provinsi Jawa Timur. Sehingga KPU kabupaten/Kota tinggal melaksanakan apa yang sudah tercantum di petunjuk teknis kegiatan maupun di RAB Kabupaten/Kota. KPU Kabupten Ngawi tidak bisa menyesuaikan dengan kebutuhan dan kondisi masyarakat Ngawi. Selain itu KPU kabupaten Ngawi tidak bisa berkreasi dan berinovasi terhadap kegiatan sosialisasi yang dilaksanakan selama tahapan pemilihan ini berlangsung. 
Dwi Ardiani, Dede Sri Kartini, Ari Ganjar Herdiansah Strategi Sosialisasi Politik Oleh KPU Kabupaten Ngawi

\section{Daftar Pustaka}

Budiarjo, M. (2016). Dasar - Dasar Ilmu Politik. Jakarta: PT. Gramedia Pustaka Utama.

BPS Kabupaten Ngawi, Kabupaten Ngawi Dalam Angka 2018 diakses pada tanggal 23 Oktober 2018 dari https://ngawikab.bps.go.id/

Creswell, J. W. (2014). Research Design : Pendekatan Metode Kualitatif, Kuantitatif, dan Campuran. Yogyakarta: Pustaka Pelajar.

Hevi Kurnia Hardiani, S.IP (2008) Perilaku Memilih dan Model Partisipasi Pada Pemilih Pemula Pada Pilkada Kota Malang,

Kholilullah P, M. I. (2014). Panduan Media Center UNtuk Optimalisasi Penyelenggaraan Pemilu. Jakarta: Yayasan Perludem.

KPU RI, Buku Pedoman Pendidikan Pemilih diakses tanggal 18 Maret 2018 dari http://kpu.go.id/koleksigambar/Buku_Pedoman_Pendidikan_Pemilih.pdf

KPU RI, Memilih Dengan Cerdas dan Cermat' diakses pada tanggal 19 Maret 2018 https://kpu.go.id/dmdocuments/modul_3bb.pdf, Memilih Dengan Cerdas dan Cermat

Michael Rush dan Philip Althoff. (2002). Pengantar Sosiologi Politik. Jakarta: Raja Grafindo Persada.

Mohtar Mas'oed \& Colin Mac Andrews. (2006). Perbandingan Sistem Politik. Yogyakarta: Gadjah Mada University Press.

Moleong, L. J. (2005). Metodologi Penelitian Kualitatif. Bandung: PT. Remaja Rosdakarya

Nursal, A. (2004). Political Marketing,Strategi Memenangkan Pemilu. Sebuah Pendekatan Baru Kampanye Pemilihan DPR, DPD, Presiden. Jakarta: PT. Gramedia Pustaka utama.

Rumah Pemilu, Pemilih Pemuda Sudah Cerdas, diakses tanggal 19 Maret 2018 dari http://www.rumahpemilu.com/public/doc/Pemilih\%20Pemuda\%20Sudah\%20Cerdas. pdf

Rumah Pemilu, Pemilih Pemula KPU DKI diakses pada tanggal 19 Maret 2018 dari http://www.rumahpemilu.com/public/doc/2013_09_30_07_07_23_20130930_TOR\% 20\%20Pendidikan\%20Pemilih\%20Pemula_KPU\%20DKI.pdf

Salusu. (2015). Pengambilan Keputusan Stratejik. Jakarta: PT. Gramedia Pustaka Utama 